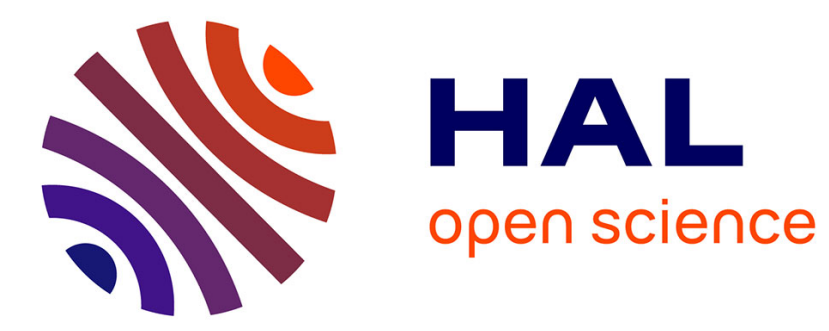

\title{
Alien versus native species as drivers of recent extinctions
}

\author{
Tim M Blackburn, Céline A Bellard, Anthony Ricciardi
}

\section{To cite this version:}

Tim M Blackburn, Céline A Bellard, Anthony Ricciardi. Alien versus native species as drivers of recent extinctions. Frontiers in Ecology and the Environment, 2019, 17 (4), pp.203-207. 10.1002/fee.2020 . hal-03252230

\section{HAL Id: hal-03252230 \\ https://hal.science/hal-03252230}

Submitted on 7 Jun 2021

HAL is a multi-disciplinary open access archive for the deposit and dissemination of scientific research documents, whether they are published or not. The documents may come from teaching and research institutions in France or abroad, or from public or private research centers.
L'archive ouverte pluridisciplinaire HAL, est destinée au dépôt et à la diffusion de documents scientifiques de niveau recherche, publiés ou non, émanant des établissements d'enseignement et de recherche français ou étrangers, des laboratoires publics ou privés. 


\section{Alien versus native species as drivers of recent extinctions}

Tim M. Blackburn ${ }^{1,2,3}$, Céline Bellard ${ }^{4}$ and Anthony Ricciardi ${ }^{3,5}$

Affiliations

${ }^{1}$ Centre for Biodiversity and Environment Research, Department of Genetics, Evolution and Environment, University College London, Gower Street, London, WC1E 6BT, UK

${ }^{2}$ Institute of Zoology, Zoological Society of London, Regent's Park, London, NW1 4RY, UK

${ }^{3}$ Centre for Invasion Biology, Department of Botany and Zoology Stellenbosch University, Matieland 7602, South Africa

${ }^{4}$ Unité Biologie des organismes et écosystèmes aquatiques (BOREA UMR 7208) Muséum national d'Histoire naturelle, Sorbonne Universités, Université Pierre et Marie Curie, Université de Caen Normandie, Université des Antilles, CNRS, IRD; 43 rue Cuvier, CP26, 75005, Paris, France

${ }^{5}$ Redpath Museum, McGill University, Montreal, Quebec, H3A 0C4, Canada

Author for correspondence: Tim M. Blackburn, Centre for Biodiversity and Environment Research, Department of Genetics, Evolution and Environment, University College London, Gower Street, London, WC1E 6BT, UK; email: t.blackburn@ucl.ac.uk 


\begin{abstract}
Native plants and animals can rapidly become superabundant and dominate ecosystems, leading some people to claim that native species are no less likely than alien species to cause environmental damage such as biodiversity loss. We compared how frequently alien species and native species have been implicated as drivers of recent extinctions in a comprehensive global database, the 2017 IUCN Red List. Alien species were considered to be a contributing cause of $25 \%$ of plant extinctions and $33 \%$ of animal extinctions, whereas native species were implicated in less than $3 \%$ and $5 \%$ of animal and plant extinctions, respectively. When listed as a putative driver of recent extinctions, native species were more often associated with cooccurring drivers than were alien species. Our results add a new line of evidence that the biogeographic origin (evolutionary history) of a species is a determining factor of its potential to cause disruptive environmental impacts.
\end{abstract}

\title{
Introduction
}

A defining feature of the Anthropocene is the human-mediated translocation of species to areas beyond their natural biogeographic boundaries (Ricciardi 2007; Kueffer 2017). Although the ecological impacts of most alien species translocations are unknown or appear to be negligible, others have been found to cause substantial changes to food webs, ecosystem function, and biodiversity (Gandhi and Herms 2010; Simberloff et al. 2013) - including extinctions on local to global scales (Clavero and García-Berthou 2005; Bellard et al. 2016a; Doherty et al. 2016; Downey and Richardson 2016). Nevertheless, some authors have argued that the impacts of alien species are exaggerated; they claim that alien species are no more likely than natives to cause environmental damage such as extinctions (Sagoff 2005; Davis et al. 2011; Pearce 2015) and that the biogeographic origin of a species is irrelevant to its impact (Davis et al. 2011; Valéry et al. 2013). Thus, it follows that efforts to control or eradicate alien 
species in general would be unnecessary and drain resources from more constructive conservation projects (Marris 2011; Pearce 2015). This view is being fuelled in part by the emerging concept of 'native invasions' - that is, native plants and animals that spread and attain extremely high abundances within their historic range (e.g. Nackley et al. 2017) and, according to some (Carey et al. 2012), can cause impacts that rival those of invasive alien species. However, as far as we are aware, no one has yet formally tested whether alien species are no more likely than natives to cause extinctions. Here, we test that claim by analysing recent global extinctions in the IUCN Red List database (IUCN 2017).

\section{Methods}

We compiled data from the 2017 IUCN Red List database (IUCN 2017) and the BirdLife International database (BirdLife International 2014) on the total numbers of extinct, possibly extinct and extinct in the wild (categories EX and EW; plant $(n=153)$ and animal (n =782)). These are species that have gone globally extinct since $1500 \mathrm{AD}$, or would have done so had the last few individuals not been taken into captivity. The IUCN Red List is widely recognized as the most comprehensive, objective global approach for evaluating the conservation status of plant and animal species. It is based on an explicit, scientifically rigorous framework for the classification of species according to their extinction risk, and is the result of the work of hundreds of experts in the status and conservation of the taxa listed (IUCN 2017). The Red List identifies 12 broad categories of extinction driver (Threats Classification Scheme version 3.2); we maintained this classification scheme for our analysis with the exception that we subdivided threat category 8 ('Invasive and other problematic species, genes $\&$ diseases') into two - alien species, and other problematic species - to give a total of 13 threat categories. The origin (native or alien) of some species in threat category 8 is unknown - we assumed that these species are native, which adds three species to the list of species threatened by natives. 
Two of these three additional species also have alien species listed as a threat. Six of the 935 extinct species had threats listed under categories 100.37 and 110.43 . These refer to old threat listings relating to pollution, and so we added these six species to the pollution threat category (Category 9 in Threats Classification Scheme version 3.2). The resulting data frame is given in WebTable 1.

We used a Chi-squared test to assess the distribution of IUCN Category 8 threats between alien and native species, and non-parametric Kruskal-Wallis tests to compare the number of other drivers associated with alien-influenced and native-influenced extinctions, conducted in R v.3.5.0 (R Core Team 2018).

\section{Results}

Of the 935 recent extinctions in our data, $33.4 \%$ of animal species $(n=261)$ and $25.5 \%$ of plant species $(\mathrm{n}=39)$ had alien species listed as one of the extinction drivers (Figure 1). Alien species rank first as a driver of animal extinctions, well ahead of biological resource use (i.e. hunting and harvesting) in second place with $18.8 \%$ of species affected. Alien species also rank first for plant extinctions, slightly ahead of biological resource use $(23.5 \%$ of extinctions) and agriculture (19.6\%). In contrast, only $2.7 \%$ of animal extinctions (21 species; rank $8^{\text {th }}$ ), and $4.6 \%$ of plant extinctions ( 7 species; rank $7^{\text {th }}$ ), had native species listed as one of the extinction drivers. In total, 261 animal extinctions since 1500AD have been associated with the impacts of alien species, more than 12 times as many as native species (21 extinctions). Alien species also outnumber native species as a driver of plant extinctions, accounting for 5.6 times as many extinctions $(n=39)$ as native species $(n=7)$. Overall, IUCN Category 8 impacts were significantly more likely to relate to alien species than to native species $\left(\chi^{2}=225\right.$, d.f. $\left.=1, \mathrm{P}<0.001\right)$. Fourteen Classes of plants and animals have suffered 
recent extinctions for which alien species are listed as a contributory driver, versus only seven Classes for which native species are listed as a driver (Figure 1).

Extinct species with one or more aliens as a driver were also associated with an average ( \pm standard deviation) of $1.00 \pm 1.24$ other extinction drivers (i.e. IUCN threat categories). The most common drivers co-occurring with alien-influenced extinctions are biological resource use (29\% of cases) and agriculture (21.7\% of cases). Species driven extinct in part by alien species had significantly more other recognised extinction drivers than species unaffected by alien species (0.42 vs 1.00; Kruskal-Wallis chi-squared $=78.1$, df $=1, \mathrm{p}<0.0001)$. Nevertheless, alien species were the sole-named driver for 126 extinct species, or $42 \%$ of the 300 species with aliens as a named driver.

Native species were the sole-named driver for no extinct species. Species with natives as an extinction driver were associated with an average of $2.57 \pm 1.50$ other extinction drivers. The most common associated drivers here were alien species (67.9\% of cases) and agriculture (57.1\%): 19 of the 28 species for which native species were listed as an extinction driver also had alien species listed as a driver. Species driven extinct in part by native species were associated with significantly more other recognised extinction drivers than species unaffected by native species ( 0.84 vs 2.57 ; Kruskal-Wallis chi-squared $=41.7, \mathrm{df}=1, \mathrm{p}<0.0001)$. Species with natives as an extinction driver were associated with more other threat types than were species with aliens as an extinction driver (2.57 vs 1.00; Kruskal-Wallis chi-squared $=33.1$, df $=1, \mathrm{p}<0.0001)$. Therefore, native species are more likely to be acting in synergy with (e.g. triggered by) other extinction drivers than are aliens. Species with both natives and aliens as extinction drivers were included in both categories in this last analysis, but the result holds if these extinctions were excluded (1.67 vs 0.86; Kruskal-Wallis chi-squared $=10.3$, df $=1, \mathrm{p}=$ 0.001). As noted above, most recently extinct species with natives listed as a driver also had aliens listed, and so the sample size was reduced in the latter analysis. 
Classes of organisms in which the majority of extinctions implicated alien species (Figure 1) include Arachnida (100\%), Diplopoda (100\%), Aves (68.9\%), Polypodiopsida $(66.7 \%)$, Clitellata (50\%), albeit that the number of extinct species in some of these Classes is small. Alien species were also implicated in $42 \%$ of reptile extinctions and $47 \%$ of mammal extinctions. In contrast, aside from Enopla $(n=1)$, native species are associated with at most $12.5 \%$ of extinctions in any class (Malacostraca). Examples of alien and native species implicated in recent extinctions are pictured in Figure 2.

\section{Discussion}

The impacts of native species in driving extinctions are much less widespread and prevalent compared with aliens, according to data derived from the assessments of the hundreds of experts who compiled the IUCN (2017) Red List (Figure 1). Alien species are implicated in the recent extinction of more than ten times as many species, of a much broader phylogenetic diversity of taxa, than native species. Our results are conservative in this regard, as we consider all extinction-driving species of unknown origin to be native species, and do not question the origins of the native species listed as causing impacts (in several cases these seem more likely to be alien). Moreover, most species do not have alien populations (Seebens et al. 2018). Thus, we provide a new line of evidence that the biogeographic origin of a species is relevant to its ecological impact, contrary to assertions that the distinction between native and alien species has no theoretical or practical importance to conservation (Davis et al. 2011; Valéry et al. 2013).

Previous analyses have shown that alien species contribute substantially to recent terrestrial vertebrate and plant extinctions as assessed by the IUCN, being the second most frequent extinction driver across all these species (after biological resource use), and the driver most frequently associated with vertebrate extinctions (Bellard et al. 2016a). The present analysis uses updated IUCN data from a broader range of taxa and reveals that alien species 
are now the primary extinction driver of both animal and plant extinctions, pushing biological resource use into second place. This may in part be due to the inclusion of extinctions in a range of taxa not analysed by Bellard et al. (2016a) where alien species have been the primary extinction driver (e.g. Arachnida, Diplopoda). Aside from birds, the proportion of extinctions ascribed to alien impacts in the taxa analysed by Bellard et al. is lower in the updated IUCN data (c.f. Figure 1 with Table 1 in Bellard et al. 2016a).

Alien taxa are not a random sample of species pools: anthropogenic mechanisms tend to select species whose attributes are conducive to invasion success, and such taxa are often introduced to areas lacking the co-evolved enemies that limit their abundance in their native range (Buckley and Catford 2015; Rejmánek and Simberloff 2017). These are among the reasons why species often generate greater ecological impacts outside their native range (Rejmánek and Simberloff 2017). Although native species can form spreading or superabundant populations, alien plants are 40 times more likely to spread rapidly and dominate communities than native plants (Simberloff et al. 2012), and they are several times more likely than natives to achieve a maximum cover of at least $80 \%$ (Seabloom et al. 2015). When native plants do undergo damaging outbreaks, such events are almost invariably triggered by anthropogenic disturbances (Simberloff et al. 2012). In this regard, it is notable that our results show that when native species are listed as a putative driver of recent extinctions, they are associated with more co-occurring extinction drivers than are recent extinctions in which native species are not implicated, or in which alien species are implicated. Indeed, no extinction in the current data was ascribed to the effects of native species alone, in contrast with 126 extinctions ascribed to the effects of alien species alone. Although alien species impacts have been argued to be frequent passengers of other environmental changes, rather than the causative drivers (Didham et al. 2005), our data suggest that passenger status is more likely for native species when it comes to recent extinctions. 
Ongoing anthropogenic disturbance, such as land transformation and climate change, can release native species from biotic constraints, perhaps causing them to dominate their communities to the detriment of native biodiversity, but anthropogenic disturbances can also create synergies with alien species that exacerbate their impacts on natives (van der Wal et al. 2008; Schweiger et al. 2010; Blaustein et al. 2011). Native species undergoing outbreaks, even those expanding their range into adjacent territory, are less likely to encounter resident natives that lack evolutionary experience with them. This is in contrast to long-distance species translocations associated with human transportation systems, which have resulted in unprecedented rates of introduction of functionally novel alien taxa into naïve recipient assemblages worldwide (Ricciardi 2007). These aliens can cause declines and extinctions in native species through a range of mechanisms, including competition (Gilbert and Levine 2013), disease transmission (Lips 2016) and predation (Doherty et al. 2016). This is particularly true for islands, where most recent extinctions have occurred, and where in the future alien species are still more likely to harm biodiversity compared to natives (Bellard et al. 2016b). Alien consumers introduced to a community where functionally similar species are absent are more likely to disrupt native species populations (e.g. Ricciardi and Atkinson 2004; Russell et al. 2017). Across different biomes and habitat types, alien predators and herbivores cause more damage than native consumers do to native populations (Salo et al. 2007; Paolucci et al. 2013). We suspect that most of the alien species introductions linked to extinctions in the IUCN database are cases of evolutionary mismatches involving naïve native populations. The accelerating rate of establishment by alien species worldwide (Seebens et al. 2017, 2018) is a particular concern in this respect.

\section{Supplementary Material}

WebTable 1. The data frame on which the analyses in this paper are based. 


\section{Acknowledgements}

We thank two anonymous referees for helpful comments that improved this manuscript.

\section{References}

Bellard C, Cassey P and Blackburn TM. 2016a. Alien species as a driver of recent extinctions. Biol Lett 12: 20150623.

Bellard C, Genovesi P and Jeschke JM. 2016b. Global patterns in threats to vertebrates by biological invasions. Proc R Soc Lond B 283: 20152454.

BirdLife International. 2014. Bird Species Distribution Maps of the World. BirdLife International, Cambridge. http://www.birdlife.org/datazone/info/spcdownload.

Blaustein AR, Han BA, Relyea RA, et al. 2011. The complexity of amphibian population declines: understanding the role of cofactors in driving amphibian losses. Ann New York Acad Sci 1223: 108-119.

Buckley YM and Catford J. 2015. Does the biogeographic origin of species matter? Ecological effects of native and non-native species and the use of origin to guide management. $J$ Ecol 104: 4-17.

Carey MP, Sanderson BL, Barnas KA, and Olden JD. 2012. Native invaders - challenges for science, management, policy, and society. Frontiers Ecol Environ 10: 373-381.

Clavero M, and García-Berthou E. 2005. Invasive species are a leading cause of animal extinction. Trends Ecol Evol 29: 110.

Davis MA, Chew MK, Hobbs RJ, et al. (2011) Don't judge species on their origins. Nature 474: $153-154$.

Didham RK, Tylianakis JM, Hutchison MA, et al. 2005. Are Invasive Species the Drivers of Ecological Change? Trends Ecol Evol 20: 470-474. 
Doherty TS, Glen AS, Nimmo DG, et al. 2016. Invasive predators and global biodiversity loss. Proc Natl Acad Sci USA 113: 11261-11265.

Downey PO and Richardson DM. 2016. Alien plant invasions and native plant extinctions. AoB Plants 8: plw047.

Gandhi KJK and Herms DA. 2010. Direct and indirect effects of alien insect herbivores on ecological processes and interactions in forests of eastern North America. Biol Inv 12: $389-405$.

Gilbert B and Levine JM. 2013. Plant invasions and extinction debts. Proc Natl Acad Sci USA 110: $1744-1749$.

IUCN 2017. The IUCN Red List of Threatened Species. Version 2017-3. http://www.iucnredlist.org. Downloaded April 2018.

Kueffer C. 2017. Plant invasions in the Anthropocene. Science 358: 724-725.

Lips KR. 2016. Overview of chytrid emergence and impacts on amphibians. Philos Trans $R$ Soc Lond B 371: 20150465.

Marris E. 2011. Rambunctious garden: Saving Nature in a post-wild world. London: Bloomsbury.

Nackley LL, West AG, Skowno AL and Bond W. 2017. The nebulous ecology of native invasions. Trends Ecol Evol 32: 814-824.

Paolucci E, MacIsaac HJ and Ricciardi A. 2013. Origin matters: alien consumers inflict greater damage on prey populations than do native consumers. Divers Distrib 19: 988-995.

Pearce F. 2015. The new wild: why invasive species will be Nature's salvation. Beacon Press.

R Core Team 2018. R: A language and environment for statistical computing. R Foundation for Statistical Computing, Vienna, Austria. https://www.R-project.org/.

Rejmánek M and Simberloff D. 2017. Origin matters. Environ Conserv 44: 97-99. 
Ricciardi A. 2007. Are modern biological invasions an unprecedented form of global change? Conserv Biol 21: 329-336.

Ricciardi A and Atkinson SK. 2004. Distinctiveness magnifies the impact of biological invaders in aquatic systems. Ecol Lett 7: 781-784.

Russell JC, Meyer J-Y, Holmes ND and Pagad S. 2017. Invasive alien species on islands: impacts, distribution, interactions and management. Environ Conserv 44: 359-370.

Sagoff M. 2005. Do non-native species threaten the natural environment? J Agric Environ Ethics 18 : 215-236.

Salo P, Korpimäki E, Banks PB, et al. 2007. Alien predators are more dangerous than native predators to prey populations. Proc R Soc Lond B 274: 1237-1243.

Schweiger O, Biesmeijer JC, Bommarco R, et al. 2010. Multiple stressors on biotic interactions: how climate change and alien species interact to affect pollination. Biol Rev 85: 777795.

Seabloom EW, Borer ET, Buckley YM, et al. 2015. Plant species' origin predicts dominance and response to nutrient enrichment and herbivores in global grasslands. Nature Commun 6: 7710.

Seebens H, Blackburn TM, Dyer EE, et al. 2017. No saturation of the accumulation of alien species worldwide. Nature Commun 8: 14435.

Seebens H, Blackburn TM, Dyer EE, et al. 2018. The global rise in emerging alien species results from increased accessibility of new source pools. Proc Natl Acad Sci USA www.pnas.org/cgi/doi/10.1073/pnas.1719429115.

Simberloff D, Martin J-L, Genovesi P, et al. 2013. Impacts of biological invasions: what's what and the way forward. Trends Ecol Evol 28: 58-66.

Simberloff D, Souza L, Munez MA, et al. 2012. The natives are restless, but not often, and mostly when disturbed. Ecology 93: 598-607. 
Valéry L, Fritz H and Lefeuvre J-C. 2013. Another call for the end of invasion biology. Oikos 122: 1143-1146.

van der Wal R, Truscott A-M, Pearce ISK, et al. 2008. Multiple anthropogenic changes cause biodiversity loss through plant invasion. Global Change Biol 14: 1428-1436. 
Figure 1. The number of recently extinct (IUCN categories EX and EW) species in each (a) plant and (b) animal Class with recorded extinctions for which alien species, native species, both alien and native species, or neither, are listed as associated extinction drivers (from data in WebTable 1).

Figure 2. Alien $(\mathrm{a}-\mathrm{c})$ and native $(\mathrm{d}-\mathrm{f})$ species cited as contributing to the extinction of species on the IUCN (2017) Red List (categories EX or EW): (a) Rosy Wolf Snail Euglandina rosea (photograph from Kauai, Hawaii, by Dylan Parker), which has been widely introduced across the Pacific as biocontrol for the giant African land snail (Achatina fulica). They have instead predated on other island endemic snail species, and are thought to have been directly responsible for the extinction of at least 134 of these (http://www.iucngisd.org/gisd/); (b) Brown Tree Snake Boiga irregularis, which according the Global Invasive Species Database (http://www.iucngisd.org/gisd/), has “decimated Guam's birds and herpetofauna, causing the local extinction of over half of Guam's native bird and lizard species [and] two out of three of Guam's native bat species", as well as several global extinctions (e.g. Guam Flycatcher Myiagra freycineti) (IUCN 2017); (c) Black Rat Rattus rattus (photograph by Bernard Dupont), which has directly contributed to the extinction of many species of birds, mammals, reptiles, invertebrates, and plants, especially on islands. Well-documented examples include extinctions of birds on Midway Island, Lord Howe Island and Big South Cape Island (http://www.iucngisd.org/gisd/); (d) Strongylocentrotus purpuratus (photograph by Laura Francis), which is implicated in the extinction of Steller's Sea Cow Hydrodamalia gigas. Human hunting of sea otters led to a population explosion of sea urchins such as S. purpuratus, which in turn largely eliminated the kelp on which the Sea Cows fed (IUCN 2017); (e) Aldabra tortoise Geochelone gigantea (photograph by Trisha M Shears), implicated in the extinction of the Aldabra Brush-Warbler 
Nesillas aldabrana. According to the IUCN Red List (IUCN 2017), this species disappeared because there is "little suitable habitat on Aldabra... It is likely that rat and cat predation was more important though, as well as degradation of its habitat by tortoises and goats."; (f) The locust Schistocerca piceifrons (photograph from Celestún Biosphere Reserve, Yucatán, México, by Katja Schulz), outbreaks of which have reduced the extent of prime habitat for the Socorro Dove Zenaida graysoni, which is extinct in the wild (IUCN 2017). 
Figure 1a

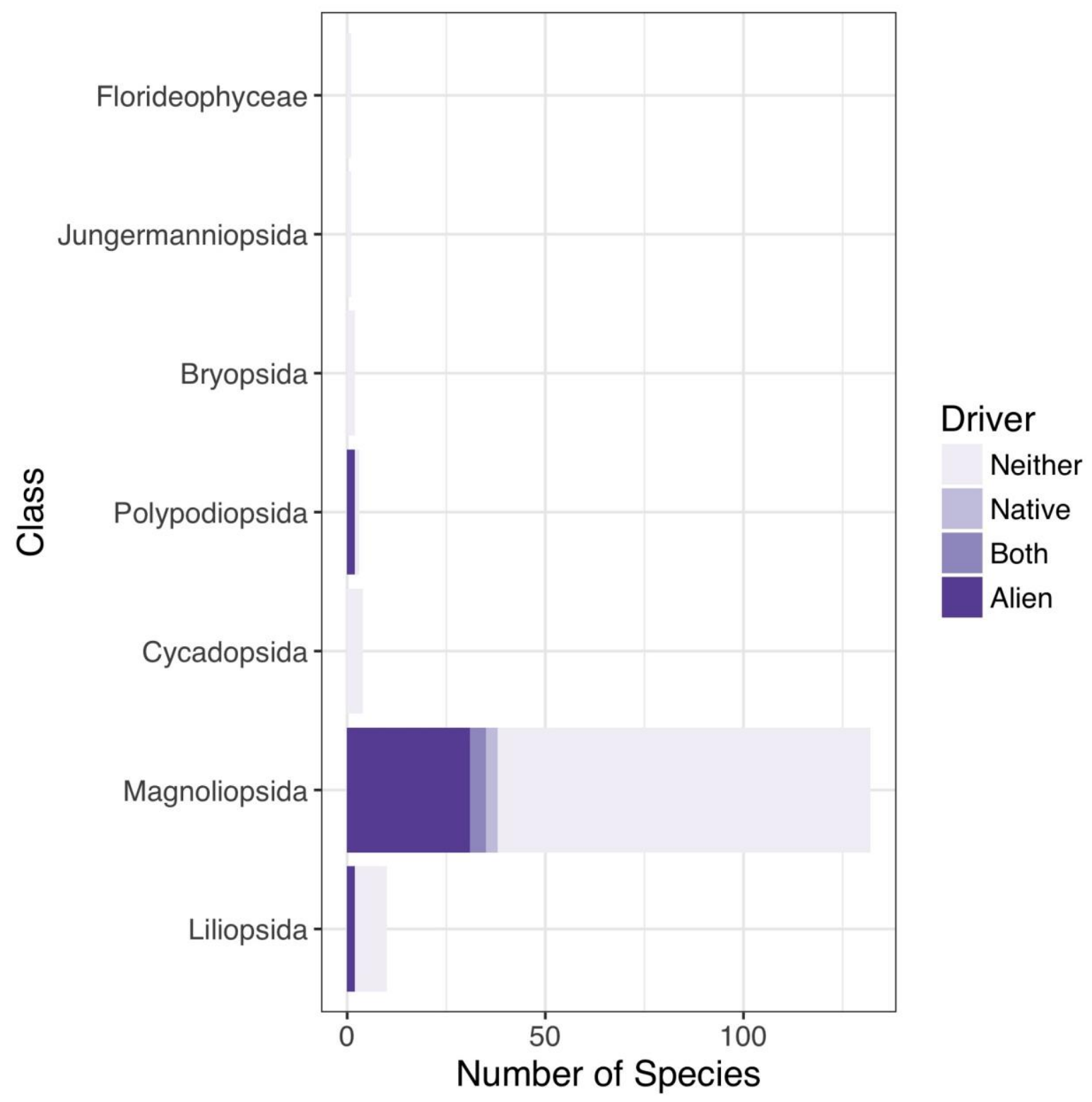


Figure $1 b$

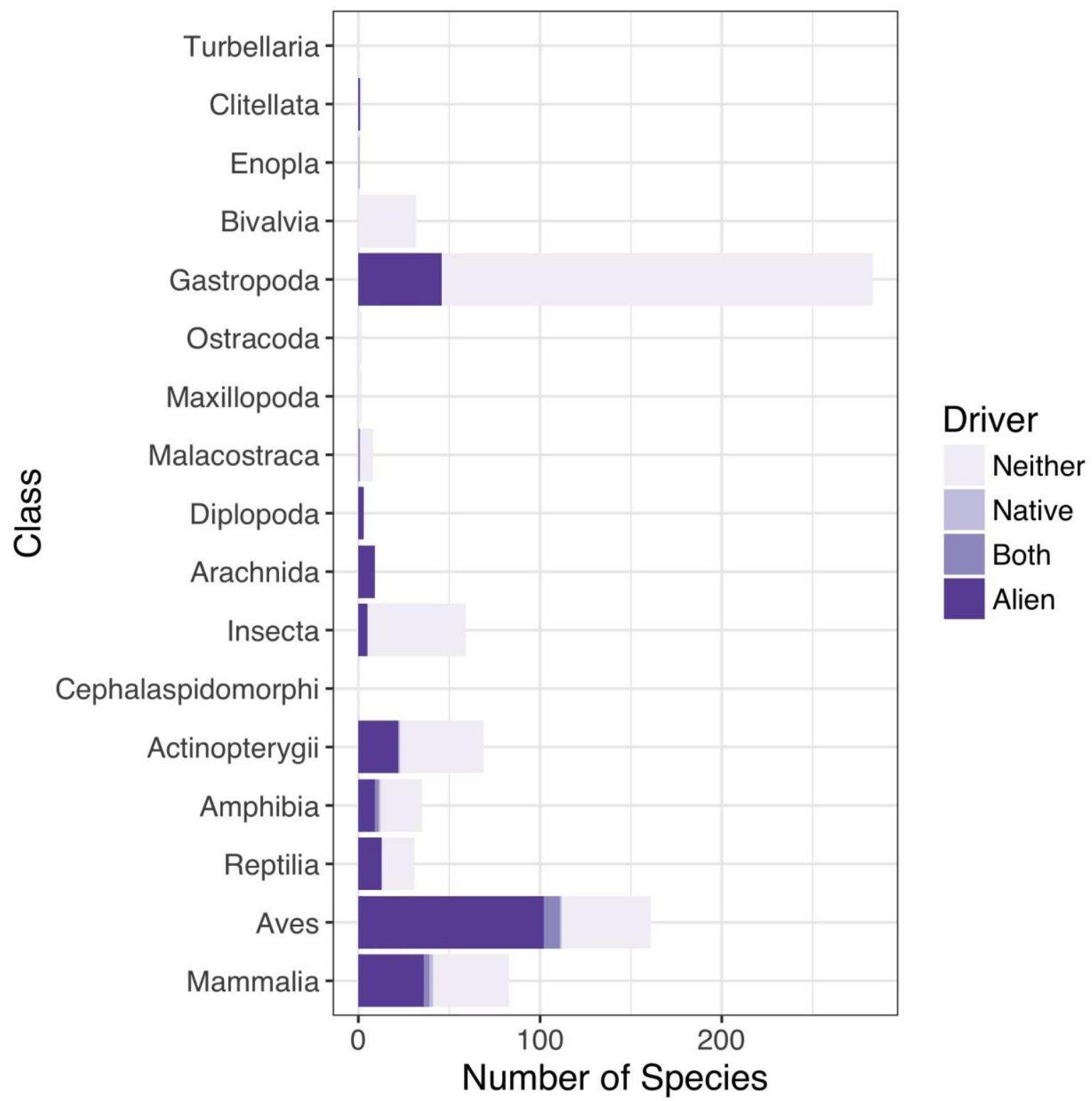


Figure 2a

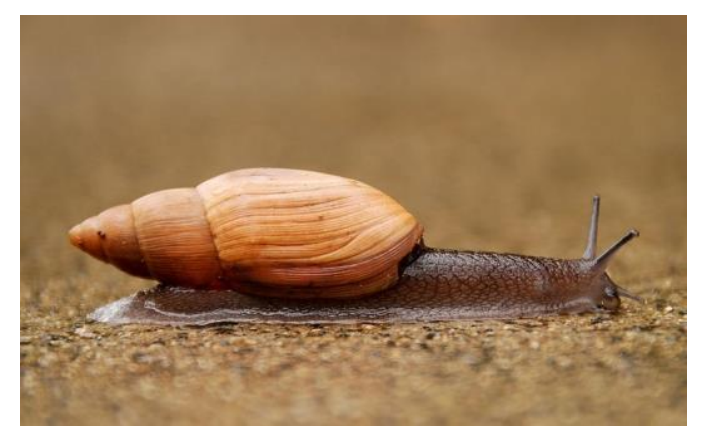

Figure 2b

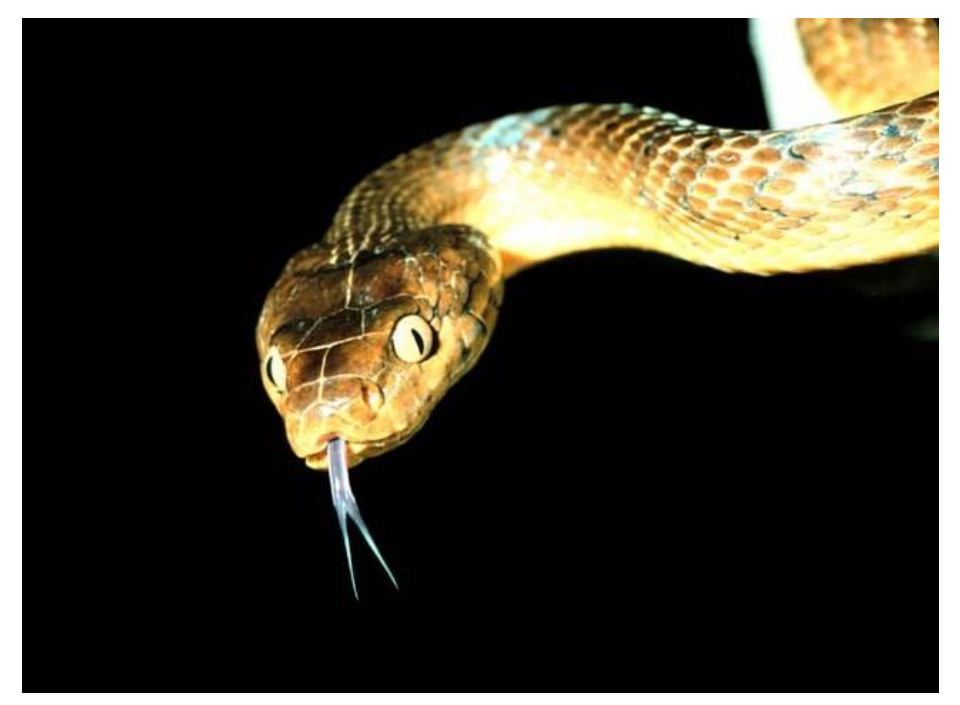

Figure 2c

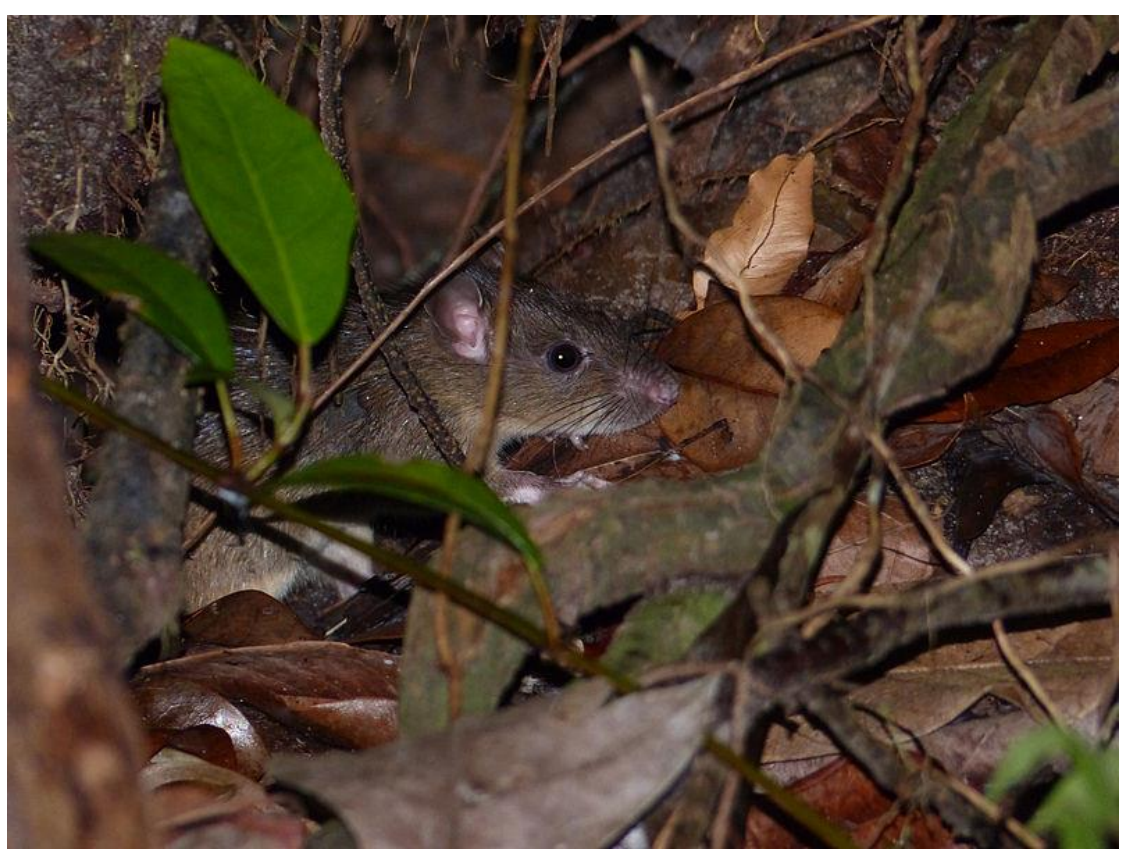


Figure 2d

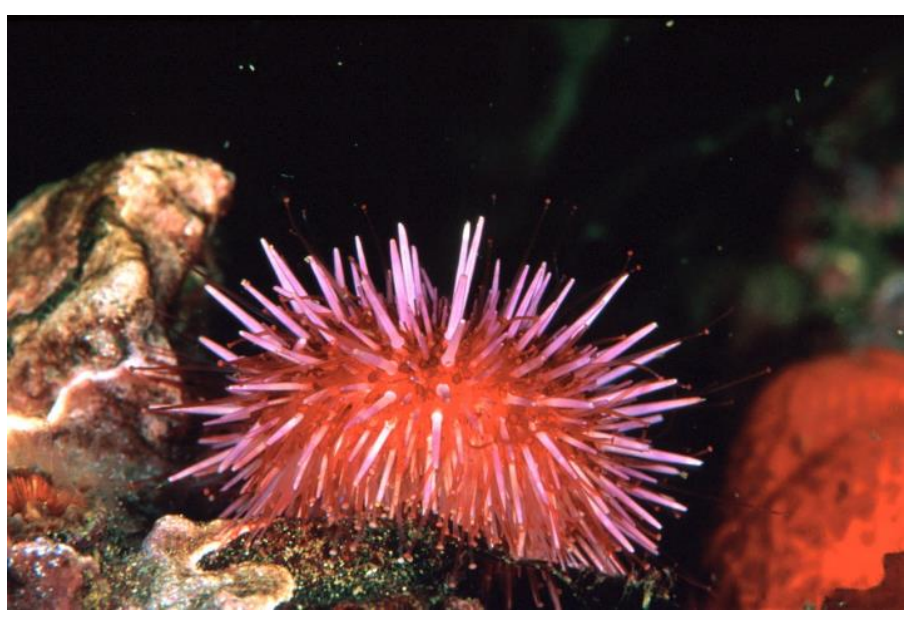

Figure 2e

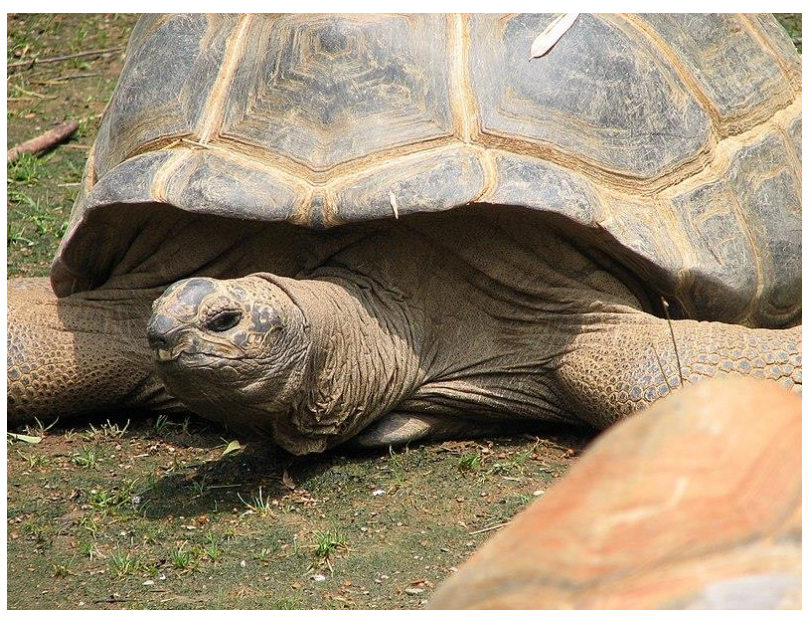

Figure $2 \mathrm{f}$

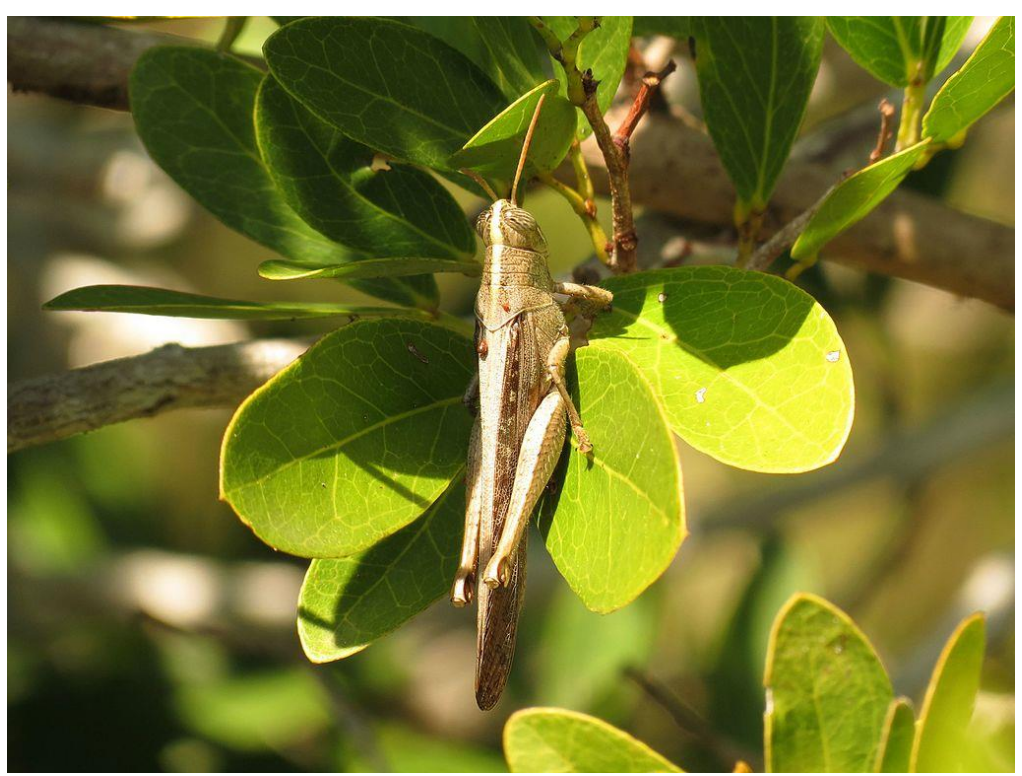


